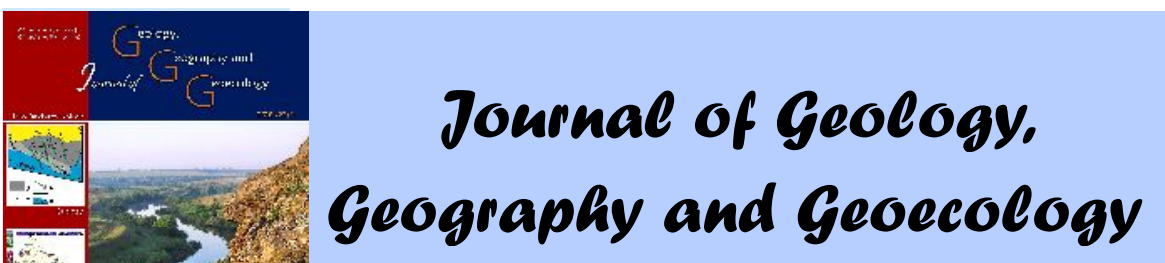

Journal home page: geology-dnu-dp.ua

\title{
Influence of technogenic loading of pyrogenic origin on the geochemical migration of heavy metals
}

\author{
Y. Buts ${ }^{1}$, V. Asotskyi ${ }^{2}$, O. Kraynyuk ${ }^{3}$, R. Ponomarenko ${ }^{4}$ \\ ${ }^{1}$ Simon Kuznets Kharkiv National University of Economics, Kharkiv, Ukraine, e-mail: butsyura@ukr.net \\ ${ }^{2}$ National University of Civil Defence of Ukraine, Kharkiv, Ukraine, e-mail: asotskiy@nuczu.edu.ua \\ ${ }^{3}$ Kharkov National Automobile and Highway University, Kharkiv, Ukraine, e-mail: alenauvarova@ukr.net \\ ${ }^{4}$ National University of Civil Defence of Ukraine, Kharkiv, Ukraine, e-mail: prv1984@ukr.net
}

Received 07.03.2018;

Received in revised form 03.04.2018; Accepted 07.06.2018
Abstract. The study of geochemical aspects of the transformation of migration properties of heavy metals under the influence of anthropogenic loading of pyrogenic origin has been given insufficient attention. We studied the concentration of heavy metals in soils by atomic absorption analysis. The results indicate the transformation of their migration properties. The diversity and versatility of behaviour of chemical elements in environmental components after fire was noted. In different ecological conditions, it is possible to observe a wide range of quantitative values of geochemical migration or accumulation of any particular chemical element. The analytical results show that the contents of migrant elements, $\mathrm{pH}$ values, areas of disasters which are approximately in the same conditions, but passed by the grass or upper fire differ quite tangibly. Heavy metals that hit the environment can form difficult soluble hydroxides. In addition, in the soil solution, there is a probability of the formation of hydroxocomplexes with different amounts of hydroxide ions by metals. The range of precipitation of hydroxides and the region of predominance of soluble hydroxocomplexes have been studied by constructing concentration-logarithmic diagrams. On the basis of the calculations it can be argued that the influence of technogenic loading of pyrogenic origin influences the geochemical migration of heavy metals . Compounds $\mathrm{Fe}^{3+}$ at the $\mathrm{pH}=4.5-14, \mathrm{Cu}^{2+}$ at $\mathrm{pH}=7-14, \mathrm{Cr}^{2+}$ at $\mathrm{pH}=7-9, \mathrm{Zn}{ }^{2+}$ at $\mathrm{pH}=8-11$, $\mathrm{Ni}^{2+}$ at $\mathrm{pH}=8-14$ have the lowest migration potential. Compounds $\mathrm{Pb}^{2+}$ at $\mathrm{pH}=9-12, \mathrm{Fe}^{2+}-\mathrm{pH}=9.5-14$ have the lowest migration potential also. In a more acidic environment, soluble substances are formed, but at a $\mathrm{pH}$ increase of only $0.5-1$, they can decrease their mobility by an order of magnitude which contributes to their concentration in the soils after the fire. In a neutral soil reaction, most of the heavy metals ( $\mathrm{Al}, \mathrm{Cr}, \mathrm{Zn}, \mathrm{Cu}, \mathrm{Fe}$ (II), Ni) are in a slightly soluble form (in the form of hydroxides), with insignificant, migration capacity which leads to the accumulation of these chemical elements in the soil. It is necessary to allocate heavy metals moving in a neutral environment ( $\mathrm{Fe}$ (II), $\mathrm{Cd}, \mathrm{Co}, \mathrm{Mg}, \mathrm{Mn}$ ) into a separate group. Any increase in $\mathrm{pH}$ values contributes to their fixation. The obtained calculations can be used to predict the geochemical migration of heavy metals in soils which result from anthropogenic disasters of a pyrogenic origin.

Key words: natural fires, migratory properties of chemical elements.

\section{плив техногенного н в нт ження пірогенного походження н геохімічну мігр цію в жких мет лів}

Анот ція. ослідженням геохімічних спектів тр нсформ ції мігр ційних вл стивостей в жких мет лів 3 впливу техногенного н в нт ження пірогенного походження приділено недост тньо ув ги. роведено дослідження концентр ції в жких мет лів у грунт х методом томно- бсорбційного н лізу. езульт ти вк зують н тр нсформ цію їх мігр ційних вл стивостей. ідмічено різном нітність т різнобічність поведінки хімічних елементів у компонент х довкілля після ур ження пожеж ми. різних екологічних умов х можн спостеріг ти широкий ді п зон кількісних зн чень геохімічної мігр ції бо кумуляції будь-якого конкретного хімічного елемент . н літичні результ ти доводять, що з вмістом елементів-мігр нтів, величин рН, 
ділянки зг рищ, які перебув ють приблизно в одн кових умов х, ле пройдені низовою бо верховою пожежею, розрізняються досить відчутно. жкі мет ли, що потр пили у довкілля, можуть утворюв ти в жкорозчинні гідроксиди. рім того, у грунтовому розчині є ймовірність утворення мет л ми гідроксокомплексів із різною кількістю гідроксид-іонів. і п зон ос дження гідроксидів і обл сті перев ж ння розчинних гідроксокомплексів вивчені з допомогою побудови концентр ційнолог рифмічних ді гр м ( ). трим ні розр хунки можн використовув ти для прогнозув ння геохімічної мігр ції в жких мет лів у грунт х як н слідків техногенних н дзвич йних ситу цій пірогенного походження.

лючові слов : природні пожежі, мігр ційні вл стивості хімічних елементів.

Introduction. In Ukraine, up to the present, there have been insufficient studies focused on the technogenic loading caused by the impact of the pyrogenic (literally - "generated by fire") factor on the environment. At the same time, the number of natural fires and their consequences continues to increase.

Materials and methods. The objective of this publication was the study of geochemical aspects of transformation of migration properties of heavy metals under the influence of technogenic pyrogenic loading.

There is no definite explanation of the conditions which influence the behaviour of microelements, particularly heavy metals (HM), under technogenic impact. The analysis of literature data does not allow determination of the diversity and multidimensional character of chemical elements in environmental components which have been affected by fires. In different ecological conditions, the range of the numerical values of the geochemical migration or accumulation of a particular chemical element can be large (Buts, Krajnjuk, 2009). For example, the concentration of mercury in soil after a ground fire ranges from $+27.3 \%$ to $64.3 \%$. Almost 2.36 times difference (Alekseenko, Gamova, 2015).

The greater part of the mass of the emissions of $\mathrm{HM}(\mathrm{Hg}, \mathrm{Cd}, \mathrm{As}, \mathrm{Pb}$, etc.) released into the atmosphere migrates in the compound of dust and aerosols. But when the analysis involves single cases of migration of ore elements $(\mathrm{Cr}, \mathrm{Ni}, \mathrm{Co}, \mathrm{Mg}$, etc) which usually passively accumulate in the burned area or adjacent areas, determination of the role of large dust particles is required.

Certainly, the migration of chemical elements occurs in relation to the type of a fire, its intensity. The higher the intensity of the fire, the higher is the numerical assessment of the air migration of chemical elements. It is pretty obvious that there are other factors which determine the behaviour of HM during fires in ecosystems.

The analytical results demonstrated that in relation to the content of migrant elements $(\mathrm{mg} / \mathrm{kg})$, $\mathrm{pH}$ values, the burned areas in nearly similar conditions but affected by ground or the crown fire significantly differ.

During a general fire, a number of chemical elements, for example mercury, cadmium, selenium and artificial radionucleoids are released from the territory of the fire, their content is $30-45 \%$ of their concentration in the areas of a ground fire (Alekseenko, Gamova, 2015). The $\mathrm{pH}$ value increases by $6-10 \%$. This is certainly related to increase in the amount of ash, which causes an alkaline reaction, though it could be partly removed from the ground surface of the burned area by aeolian or hydrologic processes. Therefore, it is not possible to exactly determine the relationship between the amount of ash and the $\mathrm{pH}$ value in the burned areas once a certain time has elapsed after the fire. The provided examples of the processes of geochemical migration clearly indicate that apart the type of the fire as a factor of chemical elements " migration from the burned areas, a major role is also played by the condition of easily combustible materials, particularly - the moisture level of the forest litter. This allows us to define another condition related to the behaviour of HM during forest fires: the physical condition of aboveground combustible materials also serves as one of the factors which determines the geochemical migration during a forest fire.

It is known that different plants differently accumulate various microelements. Therefore, one should take into account the pattern of heavy metals distribution in the above-ground parts of plants. This determines the quantitative indicators of geochemical migration of chemical elements during the fire. The most distinctive indicator is radial distribution of the HM amount in the soil section, including upper soil horizons and interlayers of felt and forest litter. In this case, there is a significant fluctuation of the $\mathrm{HM}$ concentration in the radial differentiation in the soil profile.

The burning-out of the upper parts of the steppe felt, mosses, lichen and forest litter is followed by weak emission of migrant microelements not only because the upper layers of above-ground combustible materials dry-out quicker than the lower, but also because in these horizons, their increased content is in the lower intervals, and not in the upper ones.

Therefore, it should be emphasized that the complex interaction of different chemical elements, the condition of the above-ground combustible materials and distribution of elements in the vertical sections of the soil correspond to the behaviour of chemical elements during fires in ecosystems.

During still weather when fires are spreading within ecosstems, the chemical elements held by the 
fire convectional flow migrate vertically to the upper atmospheric layers and settle down on the burned out area depending on the extent of their cooling. Wind contributes to the distribution of the smoke plume outside a pyrogenically affected area. This allows use of weather conditions to determine the role of a factor which determines the migration of chemical elements from the burned areas. However, in our opinion, this factor can be used only for small fires, for general crown fires are followed by formations of whirlwind flows which drag the cold air from the areas around the area of fire. The horizontal advectional flow of the smoke plume during such fires not only can be predicted, but could be taken into account during the fire. At the same time, dry and warm weather will be favourable for atmospheric migration, and misty and rainy weather will contribute to quick washing-out and settling of the dust and aerosolic particles of the smoke plume. All provided analyzed data indicate the presence of another factor, which the distribution of the smoke plume is related to during the fire in the ecosystem: weather conditions which influence the migration or accumulation of separate chemical elements within the burned-out territory.

No doubt that this transformation of steppe felt, forest litter, mosses, lichens, etc into different combustion products (ash, coal, dust, aerosols, etc) under the impact of high temperatures of natural fires should influence all chemical elements.

It is given that the chemical elements in the components of natural chemical complexes occur in different conditions: sorption, absorption, complex organic-mineral compounds, etc. However, in the case of forest fires, therefore high temperatures, Alekseenko I. V. (Alekseenko, Gamova, 2015) analyzes their behaviour depending on their boiling and evaporation temperatures. He assumes that active migration of cadmium and mercury is related to their low boiling temperatures, whereas because HM such as copper, chromium, nickel and cobalt have a ten times higher boiling temperature, they tended to geochemically accumulate the lithogenous base of the burned area $\left({ }^{\circ}\right): \mathrm{Hg}-357, \mathrm{As}-610$, Cs $-690, \mathrm{Cd}$ - 765, $\mathrm{Zn}-907, \mathrm{Mg}-1107, \mathrm{~Pb}-1744, \mathrm{Mn}-2151$, $\mathrm{Sr}-1384, \mathrm{Cr}-2482, \mathrm{Cu}-2595, \mathrm{Ni}-2732, \mathrm{~V}$ and Co -3000 .

The described tendency does not involve manganese - having a high boiling temperature, it easily migrates. On the other hand, a low level of migration is demonstrated by arsenic, despite the fact that this chemical element sublimates already at the temperature of $610^{\circ}$. The low values of this indicator could be caused by its position in the mineral part of the litter thickness and its close relationship with iron. The pattern also does not explain the behaviour of natrium and potassium, which accumulate in soil of burned areas, but have a low temperature gradient.

Therefore, the analysis of the data provided above suggests that the behaviour of heavy metals during fires in ecosystems depends on many factors, of which the main are: the type of fire, condition of forest combustion materials, meteorological conditions, geochemical properties of the chemical elements and the pattern of their distribution in the components of the ecosystem.

During forest fires, the high temperatures first of all affect the upper few centimeters of soil, therefore the most radical changes occur in the litter and the upper part of the humus horizon. In the process of combustion, a significant loss in the soil organic compound occurs. Affected by high temperatures, most of the carbon from the organic compound oxidizes to gaseous forms (mostly 2) and evaporates. During intense fires, elimination of organic compounds of above-ground horizons and the upper part of humus horizon occurs, and also formation of a significant amount of carbon compound of alkaline and alkaline-soil elements, which causes intensification of the $\mathrm{pH}$ reaction. According to U. M. Krasnoshhekov et al (Krasnoshhekov, Valendik, Bezkorovajnaja, 2005), the change in the acidity of soils after fires can be significant: there are recorded cases when the level of $\mathrm{pH}$ equaled from 5.7...5.9 before the fire to $\mathrm{pH}=8.7$ after the ground fire. Two months after the fire, $\mathrm{pH}$ of the surface horizon equaled 8.0, and only in the ten year old burned areas did the reaction of the upper organogenic horizons recover. Apart from the microelements necessary for the plants, which are provided to the soil from the fire, a large amount of $\mathrm{Fe}, \mathrm{Al}, \mathrm{Zn}, \mathrm{Mn}$ and other heavy metals are provided with the ash.

Let us more accurately analyse the conditions of formation of mobile forms of heavy metals in soil, which would allow us to draw a conclusion about their migration or accumulation in the geochemical environment.

Heavy metals which were released to the environment can form poorly soluble hydroxides. Also, there is a possibility that in the interstitial water, the metals will form hydroxo complexes with different amounts of hydrooxid ions (Buts, Krajnjuk, 2008). The range of sedimentation of hydroxides and the area of soluble hydroxo complexes were studied using a development of logarithmic concentration diagrams (LCD). The solution of metal hydroxide (on the example of cuprum hydroxide formation) and formation of its complex compounds is described by three main reactions:

$$
\begin{array}{ll}
\mathrm{Cu}(\mathrm{OH})_{2}=\mathrm{Cu}^{2+}+2 \mathrm{OH}^{-} & \operatorname{lgK} \mathrm{s}_{\mathrm{s}} \\
(2-\mathrm{n}) \mathrm{OH}^{-}+\mathrm{H}^{+}=\mathrm{H}_{2} \mathrm{O} & -\operatorname{lgK} \\
\mathrm{Cu}^{2+}+\mathrm{nOH}^{-}=\mathrm{Cu}(\mathrm{OH})_{\mathrm{n}}^{2-\mathrm{n}} & \lg \beta_{\mathrm{n}}
\end{array}
$$


Total reaction ум рн ре кція:

$\mathrm{Cu}(\mathrm{OH})_{2}+(2-n) \mathrm{H}^{+}=\mathrm{Cu}(\mathrm{OH})_{\mathrm{n}}{ }^{2-\mathrm{n}}+(2-\mathrm{n}) \mathrm{H}_{2} \mathrm{O}$

$\operatorname{lgK}=\lg K_{\mathrm{s}}+\lg \beta_{\mathrm{n}}-(2-\mathrm{n}) \lg \mathrm{K}_{\mathrm{w}}$

$$
\begin{array}{lll}
\mathrm{n}=1 & \mathrm{Cu}^{2+}+\mathrm{OH}^{-}=\mathrm{Cu}(\mathrm{OH})^{+} & \lg \beta_{1}=6.0 \\
\mathrm{n}=2 & \mathrm{Cu}^{2+}+2 \mathrm{OH}^{-}=\mathrm{Cu}(\mathrm{OH})_{2} & \lg \beta_{2}=13.18
\end{array}
$$

$$
\begin{array}{lll}
\mathrm{n}=3 & \mathrm{Cu}^{2+}+3 \mathrm{OH}^{-}=\mathrm{Cu}(\mathrm{OH})_{3}{ }^{-} & \lg \beta_{3}=14.42 \\
\mathrm{n}=4 & \mathrm{Cu}^{2+}+4 \mathrm{OH}^{-}=\mathrm{Cu}(\mathrm{OH})_{4} 4^{--} & \lg \beta_{4}=14.56
\end{array}
$$

For calculating the constant of balance of total reaction, we used logarithms of product of solubility of hydroxides and the constant of stability of the metal complexes with hydroxides (Table 1).

Table 1. Logarithms of constants of stability of complexes with hydroxides (Goronovskij, Nazarenko, Nekrjach, 1974; Rabinovich, Havin, 1991)

\begin{tabular}{|c|c|c|c|c|c|}
\hline Cation & $\mathrm{s}$ & $\lg \beta_{1}$ & $\lg \beta_{2}$ & $\lg \beta_{3}$ & $\lg \beta_{4}$ \\
\hline $\mathrm{Al}^{3+}$ & -32 & 9.0 & 18.7 & 27 & 33 \\
\hline $\mathrm{Cd}^{2+}$ & -13.7 & 6.08 & 8.70 & 8.38 & $8 ., 42$ \\
\hline $\mathrm{Co}^{2+}$ & -14.7 & 4.4 & 9.2 & 10.5 & \\
\hline $\mathrm{Cr}^{3+}$ & -30.18 & 10.1 & 17.8 & 24 & 29.9 \\
\hline $\mathrm{Cu}^{2+}$ & -19.66 & 6.0 & 13.18 & 14.42 & 14.56 \\
\hline $\mathrm{Fe}^{2+}$ & -15.0 & 5.56 & 9.77 & 9.67 & 8.56 \\
\hline $\mathrm{Fe}^{3+}$ & -37.42 & 11.87 & 21.17 & 30.67 & - \\
\hline $\mathrm{Mg}^{2+}$ & -9.2 & 2.60 & 16.3 & - & - \\
\hline $\mathrm{Mn}^{2+}$ & -12.7 & 3.90 & 5.8 & 8.3 & 7.7 \\
\hline $\mathrm{Ni}^{2+}$ & -18.06 & 4.97 & 8.55 & 11.33 & 12 \\
\hline $\mathrm{Zn}^{2+}$ & -17 & 6.31 & 11.19 & 14.31 & 17.70 \\
\hline $\mathrm{Hg}^{2+}$ & -25.44 & 10.59 & 21.82 & 20.89 & 10.67 \\
\hline $\mathrm{Pb}^{2+}$ & -14.9 & 6.29 & 10.87 & 13.39 & $\bullet$ \\
\hline
\end{tabular}

Equivalent concentrations of metal-containing particles in this case will be as follows:

$\lg \left[\mathrm{u}(\mathrm{OH})_{\mathrm{n}}^{2-\mathrm{n}}\right]=\lg \mathrm{K}_{\mathrm{s}}+\lg \beta_{\mathrm{n}}-(2-\mathrm{n}) \lg \mathrm{K}_{\mathrm{w}}-(2-\mathrm{n}) \mathrm{pH}$

$\mathrm{n}=0 \quad \lg \left[\mathrm{u}^{2+}\right]=\lg \mathrm{K}_{\mathrm{s}}-2 \lg \mathrm{K}_{\mathrm{w}}-2 \mathrm{pH}=8.34-2 \mathrm{pH}$

$\mathrm{n}=1 \quad \lg \left[\mathrm{Cu}(\mathrm{OH})^{+}\right]=\lg \mathrm{K}_{\mathrm{s}}+\lg \beta_{1}-\lg \mathrm{K}_{\mathrm{w}}-\mathrm{pH}=0.34-\mathrm{pH}$

$\mathrm{n}=2 \quad \lg \left[\mathrm{Cu}(\mathrm{OH})_{2}\right]=\lg \mathrm{K}_{\mathrm{s}}+\lg \beta_{2}=-6.48$

$\mathrm{n}=3 \quad \lg \left[\mathrm{Cu}(\mathrm{OH})_{3}{ }^{-}\right]=\lg \mathrm{K}_{\mathrm{s}}+\lg \beta_{3}+\lg \mathrm{K}_{\mathrm{w}}+\mathrm{pH}=$ $=-19.24+\mathrm{pH}$

$\mathrm{n}=4 \lg \left[\mathrm{Cu}(\mathrm{OH})_{4}^{2-}\right]=\lg \mathrm{K}_{\mathrm{s}}+\lg \beta_{4}+2 \lg \mathrm{K}_{\mathrm{w}}+2 \mathrm{pH}=$ $=-33.1+2 \mathrm{pH}$

Therefore, in the provided diagrams (Fig. 1), we can clearly determine the areas of maximum sedimentation of metal hydroxides (Fig, 2). The condition of $\mathrm{e}^{\mathrm{zt}}$ sedimentation was assumed its concentration in the interstitial water equaling $10^{-5} \mathrm{~mol} / \mathrm{l}$. Therefore (Fig. 1), below pH6.8, cuprum is in a dissolved state, and at higher $\mathrm{pH}$ values, cuprum settles down as a hydroxide $\mathrm{Cu}(\mathrm{OH})_{2}$, and at significantly high $\mathrm{pH} 13$ values, develops $\mathrm{Cu}(\mathrm{OH})_{3}$ hydroxo complexes, but their concentration is low, so one can conclude that cuprum compounds have a high level of migration activity to a neutral environment and their fixations at pH6.8. We developed assessments and diagrams for a number of metals (Figs. 1-6).

Results and their analysis. The LCD intervals of hydroxide sedimentation, which we developed, coincide with the data by U. U. Lur'e (Lur'e, 1989).

In a neutral soil, most metals $(\mathrm{Al}, \mathrm{Cr}, \mathrm{Zn}, \mathrm{Cu}$, $\mathrm{Fe}$ (II), Co, Ni) occur in heavy soluble form (hydroxides). At the same time, their migrational property is not significant, which leads to accumulation of chemical elements in soil (Fig. 2). In such conditions, heavy metals do not become washed-out from the soil, are not consumed by plants, but accumulate in the soil.

A significant change in the $\mathrm{pH}$, for example the one recorded by U. M. Krasnoshhekov et al (Krasnoshhekov, Valendik, Bezkorovajnaja, 2005) causes radical changes in the behaviour of the cuprum compounds. At $\mathrm{pH}=5.7$ before the fire, the concentration $\left[\mathrm{Cu}^{+2}\right]=0.01 \mathrm{~mol} / \mathrm{l}$, whereas at $\mathrm{p}=8.7$ after the fire, all cuprum accumulates in soil in nonsoluble form.

Ions of $\mathrm{Fe}^{2+}$ easily migrate in acidic, neutral and even insignificantly alkaline environments to $\mathrm{pH}=9.5$, forming $\mathrm{Fe}(\mathrm{OH})_{2}$ hydroxide only in a highly alkaline environment (Fig. 2).

Radically different behaviour was observed in ions of Ferum (III). In a highly acidic environment, they occurred in the form of $\mathrm{Fe}^{3+}$ and $\mathrm{Fe}(\mathrm{OH})^{2+}$, and already at $\mathrm{pH} 5$, non-soluble $\mathrm{Fe}(\mathrm{OH})_{3}$ hydroxide forms. That means at increasing level of $\mathrm{pH}$ after the fire, Ferum (III) will always accumulate in soil (Fig. $3)$. 


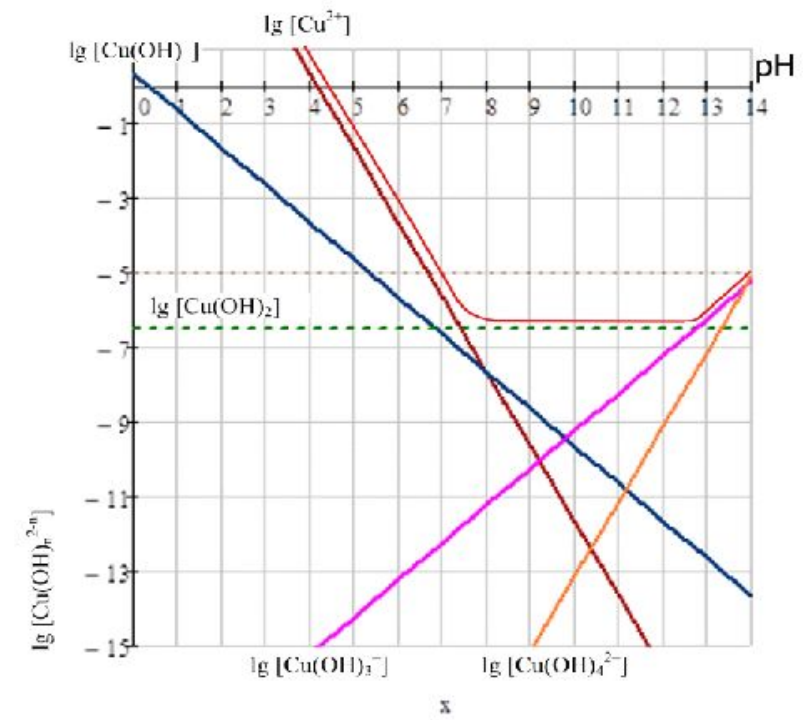

Fig. 1. Logarithmic concentration diagram (LCD) of forming of hydroxo complex of cuprum

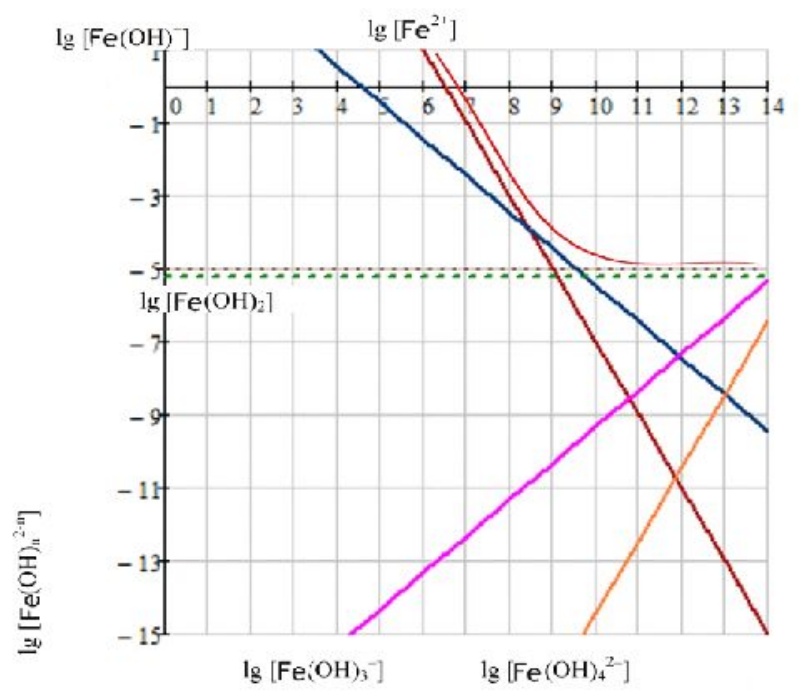

Fig. 2. Logarithmic concentration diagram of formation of hydroxo complexes of ferum (II)

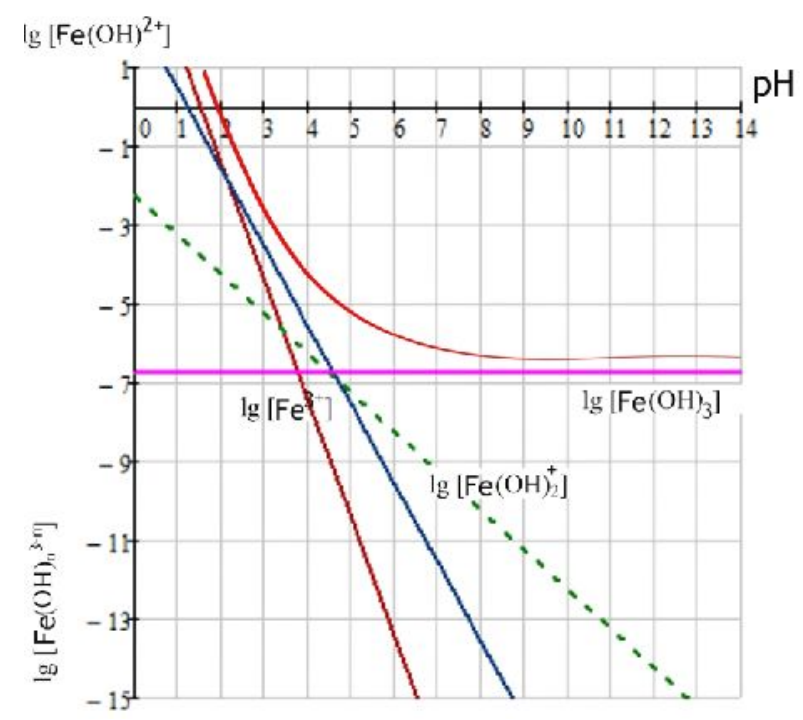

Fig. 3. Logorithmic concentration diagram of formation of hydroxo complexes of Ferum (III) 
Zinc compounds behave in different environments as follows (Fig. 4): in acidic and neutral environments, there are ions of $\mathrm{Zn}^{2+}$, and at $\mathrm{pH}=8-11.5$, a non-soluble $\mathrm{Zn}(\mathrm{OH})_{2}$ hydroxide forms; in highly alkaline environments, zinc becomes mobile in the form of $\mathrm{Zn}(\mathrm{OH})_{2}{ }^{2-}$ hydroxo complexes.

In conditions, as for example described by $\mathrm{U}$. M. Krasnoshhekov et al. (Krasnoshhekov, Valendik, Bezkorovajnaja, 2005), at $\mathrm{pH}=5.7 . .5 .9$ acidity before the fire, the concentration of mobile zinc can be up to $\lg \left[\mathrm{Zn}^{2+}\right]=-1$, i.e. to $0.1 \mathrm{~mol} / \mathrm{l}$, and $\lg \left[\mathrm{Zn}^{2+}\right]=-4$ at $\mathrm{p}=8.7$ after the fire, i.e. the mobile forms in the soil environment equaled only $0.0001 \mathrm{~mol} / 1$, i.e. zinc transforms into non-soluble forms and accumulates.

For nickel compounds, we observed the fol- lowing relationship (Fig. 5): in acidic and neutral environments, the mobile forms of nickel compounds dominate, but after a change in $\mathrm{pH}$, for example even 5.5 to 6.0 , the number of mobile forms of nickel decreased by 10 times from $\lg \left[\mathrm{Ni}^{2+}\right]=-1$ to $\lg \left[\mathrm{Ni}^{2+}\right]=-$ 2, i.e. the concentration of $\mathrm{Cu}^{2+}$ ions changed from $0.1 \mathrm{~mol} / \mathrm{l}$ to $0.01 \mathrm{~mol} / \mathrm{l}$ at $\mathrm{pH}$ increase from 5.5 to 6.0. At $\mathrm{pH}$ 8, the nickel compounds remained in nonsoluble form.

At $\mathrm{pH}$ 9, plumbum is in a mobile form, nonsoluble complexes and hydroxides can dominate only in alkaline and highly alkaline environments (Fig. 6). With increase in $\mathrm{pH}$, the concentration of mobile forms rapidly decreases.

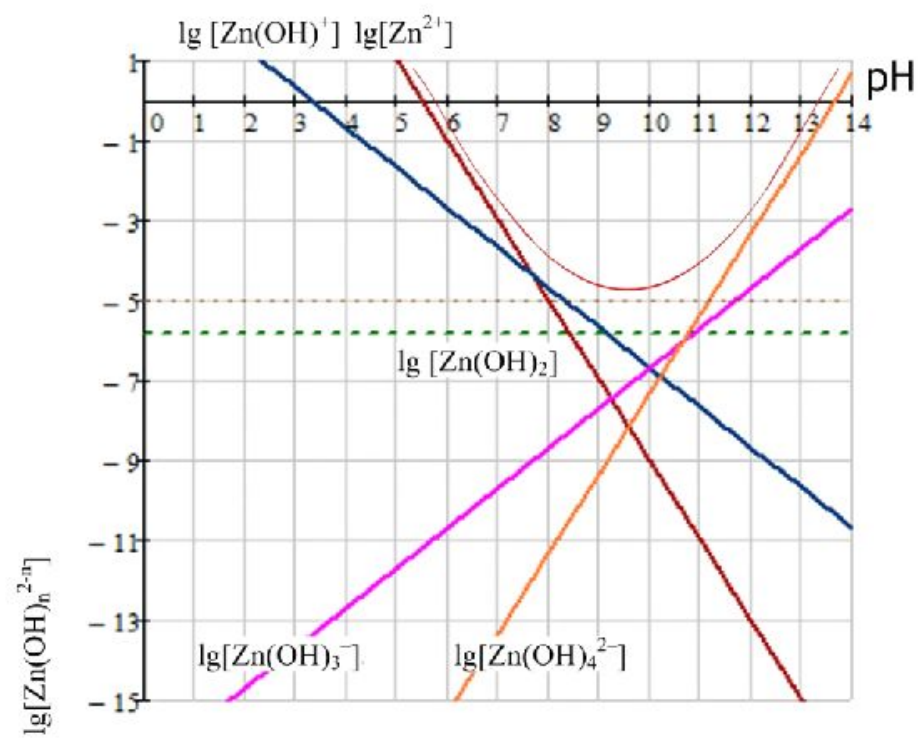

Fig. 4. Logorithmic concentration diagram of formation of zinc hydroxo complexes

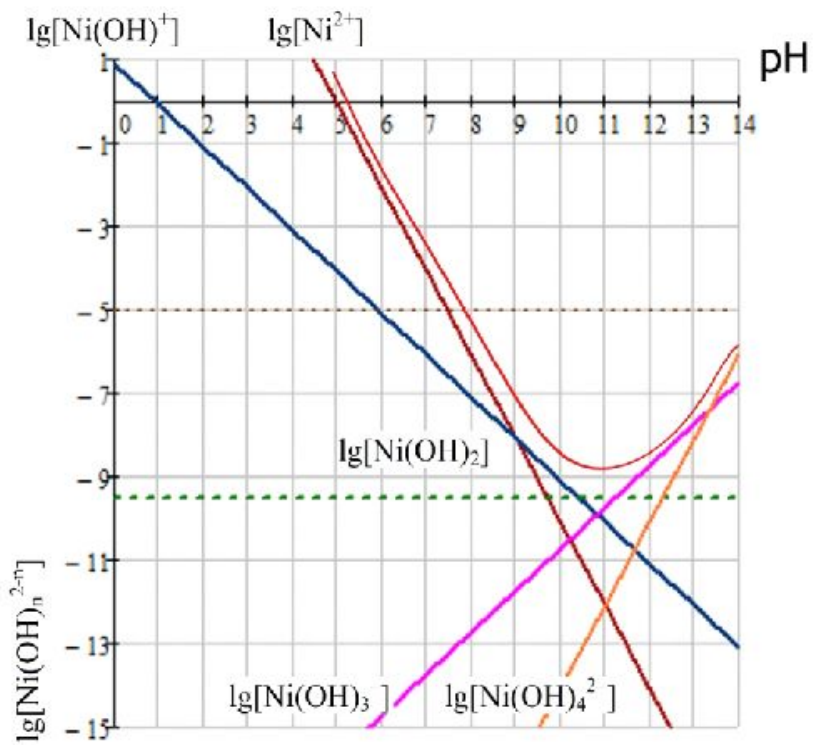

Fig. 5. Logarithmic concentration diagram of formation of hydroxo complexes of nickel 


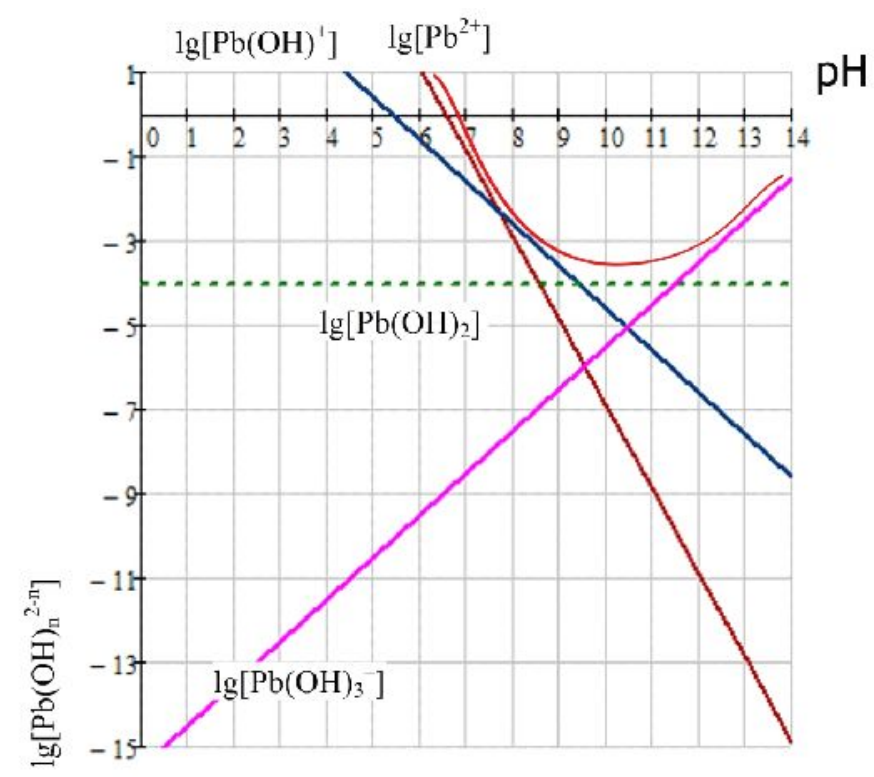

Fig. 6. Logarithmic concentration diagram of formation of hydroxo complexes of plumbum.

Chromium compounds (III) will behave as follows (Fig. 7): in acidic environments, soluble, i.e. mobile forms of $\mathrm{Cr}^{3+}$ dominate, but their concentration rapidly decreases with increase in $\mathrm{pH}$. For example, if at $\mathrm{pH}=5$, the concentration of mobile forms of chromium could equal $0.01 \mathrm{~mol} / \mathrm{l}$, at $\mathrm{pH}=5.7$ it equaled $0.001 \mathrm{~mol} / \mathrm{l}$. That means that during the impact of fire, chromium will accumulate in soil. In neutral environments, chromium forms a non-soluble hydroxide, in alkaline environments, at $\mathrm{pH}=8.5 \ldots 9$, it starts forming soluble $\mathrm{Cr}(\mathrm{OH})_{4}{ }^{-}$hydroxo complexes.

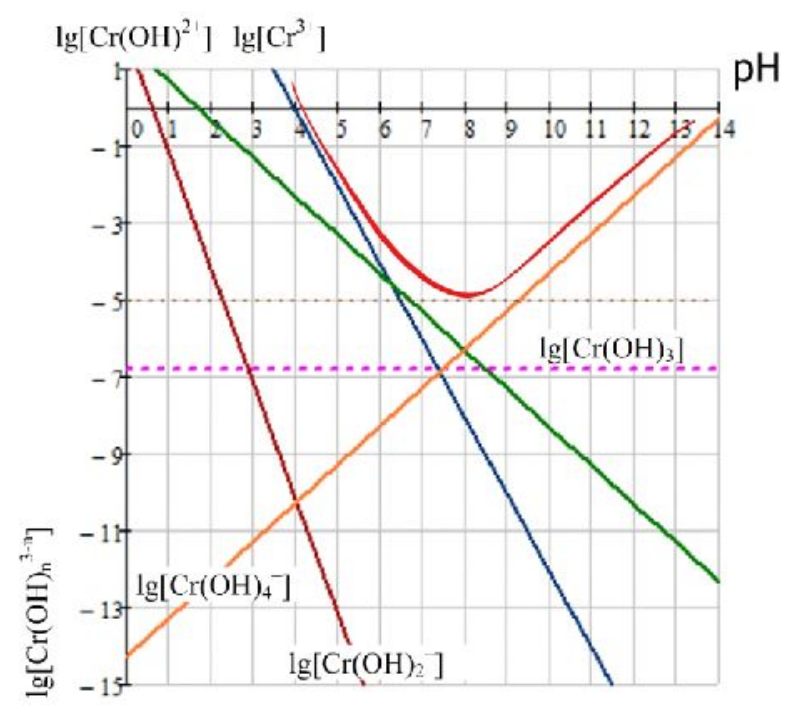

Fig. 7. Logarithmic concentration diagram of forming of chromium hydroxo complexes.

Conclusions. According to our assessments, we can state that technogenic loading of pyrogenic origin has an impact on the geochemical migration of heavy metals . The lowest migration properties were demonstrated by the $\mathrm{Fe}^{3+}$ compounds at $\mathrm{pH}=4.5-14$, $\mathrm{Cu}^{2+}$ - at $\mathrm{pH}=7-14, \mathrm{Cr}^{2+}-$ at $\mathrm{pH}=7-9, \mathrm{Zn}^{2+}$ at $\mathrm{pH}=8-$ $11, \mathrm{Ni}-$ at $\mathrm{PH}=8-14, \mathrm{~Pb}^{2+}-$ at $\mathrm{pH}=9-12, \mathrm{Fe}^{2+}-$ at $\mathrm{pH}=9.5-14$. In more acidic environments, soluble compounds form, but a mere 0.5-1 times increase in the $\mathrm{pH}$ can decrease their mobility ten times, causing their accumulation in soil after a forest fire.

In the soil which is neutral in relation to reaction, most heavy metals (Al, Cr, $\mathrm{Zn}, \mathrm{Cu}, \mathrm{Fe}$ (II), Ni) are present in hard-soluble form (hydroxides), at the same time their migrational ability is low, thus causing accumulation of these chemical elements in soil. окрему групу слід виділити в жкі мет ли рухомі у нейтр льному середовищі (Fe (II), Cd, $\mathrm{o}, \mathrm{Mg}, \mathrm{Mn})$. удь-яке підвищення зн чень $\mathrm{p}$ сприяє їх фікс ції.

трим ні розр хунки можн використовув ти для прогнозув ння геохімічної мігр ції в жких мет лів у грунт х після техногенних н слідків н дзвич йних ситу цій пірогенного походження.

The heavy metals which are mobile in neutral 
environments (Fe (II), Cd, o, Mg, Mn) should be united in a separate group. Any $\mathrm{pH}$ increase contributes to their fixation.

The developed calculations can be used for predicting geochemical migration of heavy metals in soils after technogenic impacts of a disaster of a pyrogenic origin.

\section{References}

Alekseenko I.V. Gamova N.S., 2015 Vlijanie lesnyh pozharov na svojstva pochv tajozhnyh landshaftov hrebta Hamar-Daban. [Influence of forest fires on soil properties of taiga landscapes of the KhamarDaban Range]. Biogeohimija tehnogeneza i sovremennye problemy geohimicheskoj jekologii. Barnaul, 1, 171-174 (in Russian).

Buts Ju.V., Krajnjuk O.V., 2009 Zabrudnennja vazhkimi metalami landshaftnih kompleksiv jak rezul'tat tehnogenno-ekologichnogo navantazhennja. [Pollution by heavy metals of landscape complexes as a result of technogenic and ecological load]. National University of Civil Defence of Ukraine, Kharkiv (in Ukrainian).
Buts Ju.V., Krajnjuk E.V., 2008 Modelirovanie migracionnoj sposobnosti tjazhelyh metallov pri chrezvychajnyh situacijah tehnogennogo haraktera. [Modeling the migration ability of heavy metals in emergency situations of anthropogenic nature]. Russian Military Medical Academy (in Russian).

Krasnoshhekov Ju.N., Valendik. Je.N., Bezkorovajnaja I.N., Verhovec S.V., Kisiljahov E.K., Kuz'michenko V.V, 2005 Vlijanie kontroliruemogo vyzhiganija shelkoprjadnikov na svojstva dernovo-podzolistyh pochv v Nizhnem Priangar'e. [The effect of controlled silkworm burning on the properties of sod-podzolic soils in the Lower Angara]. Lesovedenie (in Russian).

Goronovskij I.T., Nazarenko Ju.P., Nekrjach E.F., 1974 Kratkij himicheskij spravochnik [Brief Chemical Handbook]. Kiev (in Russian).

Rabinovich V. A., Havin Z. Ja., 1991 Kratkij himicheskij spravochnik [Brief Chemical Handbook]. Sprav. Izd, Leningrad (in Russian).

Lur'e Ju. Ju., 1989 Spravochnik po analiticheskoj himii [Handbook of Analytical Chemistry]. Moskva (in Russian). 